\title{
2.5D RELATIVISTIC ELECTROMAGNETIC PIC CODE FOR SIMULATION OF BEAM INTERACTION WITH PLASMA IN AXIAL-SYMMETRIC GEOMETRY
}

\author{
Yu.M. Tolochkevych, T.E. Litoshenko, I.O. Anisimov \\ Taras Shevchenko National University of Kiev, Radio Physics Faculty, Kiev, Ukraine \\ E-mail: yura.tolochkevych@gmail.com; taras.litoshenko@gmail.com;ioa@univ.kiev.ua
}

2.5D relativistic electromagnetic PIC code for simulation of beam interaction with plasma in axial-symmetric geometry was developed. Accurate charge weighting scheme and difference schemes near the system axis were introduced. Simulation tests of electromagnetic wave interaction with inhomogeneous plasma were carried out.

PACS: 52.65-y

\section{INTRODUCTION}

A lot of problems in plasma electronics (the nonlinear stage of beam-plasma interaction, dynamics of electron bunches in wake fields excited by them in plasma, the Bursian effect in injection of strong electron bunches, etc.) can be solved only by means of computer simulation.

The method of particles in cells is used intensively numerical simulation of plasma [1]. This method is used for the simulation of phenomena in space, ionosphere, various discharges, plasma display cells etc.

Majority of existing programs for beam-plasma simulation are electrostatic. But using such codes [2-3] we cannot observe effects of electromagnetic waves propagation or radiation in plasmas. The equations of particles motion which are integrated are not relativistic, but it is necessary to solve the relativistic equations of motion in many cases.

The aim of this work is to present the relativistic electromagnetic code for beam-plasma systems simulation with axial symmetry using a method of particles in cells with a longitudinal magnetic field.

\section{THE DIFFERENCE SCHEMES DESCRIPTION}

The two-dimensional cell in cylindrical coordinates ( $\mathrm{r}-\mathrm{z})$ for the presented axial-symmetric code is showed on Fig.1. Points are marked where each component of field, potential, charge and current are calculated. Large particle have a shape of the ring which can move along $z$ axis, vary its radius moving in radial direction and rotate azimuthally. It is possible to simulate propagation of electromagnetic waves of $E$ type in two dimensional systems without $z$ component of magnetic field $H$ accordingly. But in some cases the presence of this component is important (e.g., dynamics of an electron bunch injected along the magnetic field).

In the proposed code the space grid remains twodimensional, but large particles have three components of velocity which results in three components of electric and magnetic field. Therefore electromagnetic waves of $H$ type arise in the system.

For solution of Maxwell equations' set the method of finite differences in time domain (FDTD) was used [4-5]. This method is based on Yee algorithm, which allows finding both electrical and magnetic field in time and space using first pair of the Maxwell equations (the law of Ampere's circuital law with Maxwell's correction and the electromagnetic induction law).

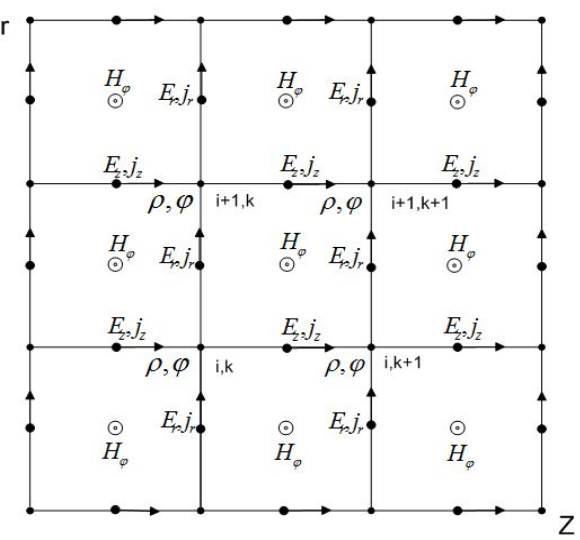

Fig.1. Elementary cell for 2D model

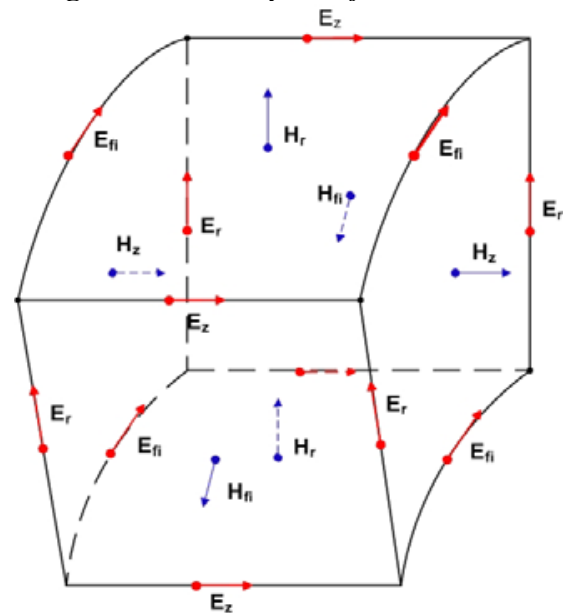

Fig.2. Elementary $3 D$ cell in cylindrical geometry

$3 \mathrm{D}$ elementary cell in cylindrical geometry is represented on Fig.2. Each point where electric field component is calculated is surrounded in a plane perpendicular to its direction by four points, where magnetic field components are calculated. Oppositely, each point where the magnetic field component is calculated is surrounded by four points where electric field components are calculated.

Thus difference schemes for $E$ and $H$ components of the field take a form:

$$
\begin{aligned}
& \left.E_{r}\right|_{i+1 / 2, k} ^{n+1}=\left.E_{r}\right|_{i+1 / 2, k} ^{n}- \\
& -\left[\left.j_{r}\right|_{i+1 / 2, k} ^{n+1 / 2}+\frac{1}{\Delta z}\left(\left.H_{\varphi}\right|_{i+1 / 2, k+1 / 2} ^{n+1 / 2}-\left.H_{\varphi}\right|_{i+1 / 2, k-1 / 2} ^{n+1 / 2}\right)\right] \frac{\Delta t}{\varepsilon_{0} \varepsilon_{i+1 / 2, k}} ;
\end{aligned}
$$




$$
\begin{aligned}
& \left.E_{\varphi}\right|_{i, k} ^{n+1}=\left.E_{r}\right|_{i, k} ^{n}-\left[\left.j_{\varphi}\right|_{i, k} ^{n+1 / 2}-\frac{1}{\Delta z}\left(\left.H_{r}\right|_{i, k+1 / 2} ^{n+1 / 2}-\left.H_{r}\right|_{i, k-1 / 2} ^{n+1 / 2}\right)+\right.
\end{aligned}
$$

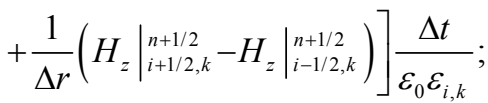

$$
\begin{aligned}
& \left.E_{z}\right|_{i, k+1 / 2} ^{n+1}=\left.E_{z}\right|_{i, k+1 / 2} ^{n}-\left[\left.j_{z}\right|_{i, k+1 / 2} ^{n+1 / 2}-\frac{1}{2 \Delta r i}\left(\left.H_{\varphi}\right|_{i+1 / 2, k} ^{n+1 / 2}+\left.H_{\varphi}\right|_{i-1 / 2, k} ^{n+1 / 2}\right)+\right. \\
& \left.+\frac{1}{\Delta r}\left(\left.H_{\varphi}\right|_{i+1 / 2, k+1 / 2} ^{n+1 / 2}-\left.H_{\varphi}\right|_{i-1 / 2, k+1 / 2} ^{n+1 / 2}\right)\right] \frac{\Delta t}{\varepsilon_{0} \varepsilon_{i, k}} ;
\end{aligned}
$$

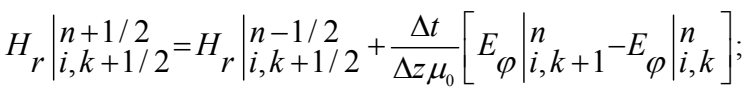

$$
\begin{aligned}
& H_{\varphi}\left|\begin{array}{l}
n+1 / 2 \\
i+1 / 2, k+1 / 2
\end{array}=H_{\varphi}\right| \begin{array}{l}
n-1 / 2 \\
i+1 / 2, k+1 / 2^{-}
\end{array} \\
& -\left[\frac{1}{\Delta z}\left(E_{r}\left|\begin{array}{l}
n \\
i+1 / 2, k
\end{array}-E_{r}\right| \begin{array}{l}
n \\
i, k
\end{array}\right)-\right. \\
& \left.-\frac{1}{\Delta r}\left(E_{z}\left|\begin{array}{l}
n \\
i+1, k+1 / 2
\end{array}-E_{z}\right| \begin{array}{l}
n \\
i, k+1 / 2
\end{array}\right)\right] \frac{\Delta t}{\mu_{0}} ; \\
& H_{z}\left|\begin{array}{l|l}
n+1 / 2 \\
i, k+1 / 2
\end{array}=H_{z}\right| \begin{array}{l}
n-1 / 2 \\
i+1 / 2, k
\end{array}- \\
& {\left[\frac{1}{2 \Delta r(i+1 / 2)}\left(E_{\varphi}\left|\begin{array}{l}
n \\
i+1, k
\end{array}+E_{\varphi}\right| \begin{array}{l}
n \\
i, k
\end{array}\right)+\right.} \\
& \left.+\frac{1}{\Delta r}\left(E_{\varphi}\left|\begin{array}{l}
n \\
i+1, k
\end{array}-E_{\varphi}\right| \begin{array}{l}
n \\
i, k
\end{array}\right)\right] \frac{\Delta t}{\mu_{0}} .
\end{aligned}
$$

\section{FEATURES OF NEAR AXIS CALCULATIONS}

Solution of equations (1)-(2) has some specific features in the cylindrical coordinate system connected with the calculation of field's components near the system axis. One can see from Fig.2 that electromagnetic field components $E_{\varphi}, E_{\mathrm{z}}$ and $H_{\mathrm{r}}$ are found on the axis, and $E_{\mathrm{r}}, H_{\varphi}$ and $H_{\mathrm{z}}$ components are found at the distance $\Delta r / 2$ from the axis.

On the axis $H_{\mathrm{r}}=0$, but the set (1)-(2) cannot be used for $E_{\mathrm{z}}$ and $E_{\varphi}$ calculation near the axis. Therefore, the first Maxwell equation in the integral form should be used in order to obtain the field near the axis:

$$
\oint_{l} H d l=I+\oiint_{S} \frac{\partial D}{\partial t} d S .
$$

Calculating integral for the cell allocated on the system axis (see Fig. 3,a) and taking into account that its radius is equal to $\Delta r / 2$, it is possible to obtain $E_{\mathrm{z}}$ :

$$
\begin{aligned}
& \begin{array}{l|l|l}
E_{z} & \begin{array}{l}
n+1 \\
0, k+1 / 2
\end{array}
\end{array}=E_{z} \mid \begin{array}{l}
n \\
0, k+1 / 2
\end{array}-
\end{aligned}
$$

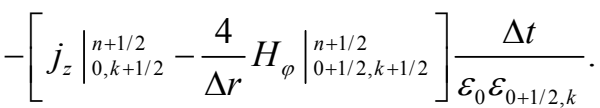

$E_{\varphi}$ is calculated similarly (see Fig. 3,b):

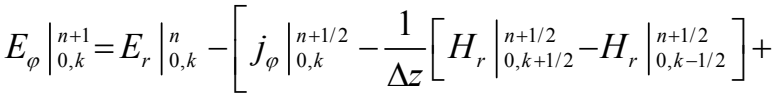

$$
\begin{aligned}
& \left.+\left.\frac{2}{\Delta r} H_{z}\right|_{0, k+1 / 2} ^{n+1 / 2}\right] \frac{\Delta t}{\varepsilon_{0} \varepsilon_{i, k}} .
\end{aligned}
$$

On the system axis $j_{\varphi}=0$ and $H_{\mathrm{r}}=0$, equation (5) can be rewritten in the form:

$$
\left.E_{\varphi}\right|_{0, k} ^{n+1}=\left.E_{r}\right|_{0, k} ^{n}-\left[\left.\frac{2}{\Delta r} H_{z}\right|_{0, k+1 / 2} ^{n+1 / 2}\right] \frac{\Delta t}{\varepsilon_{0} \varepsilon_{i, k}} .
$$
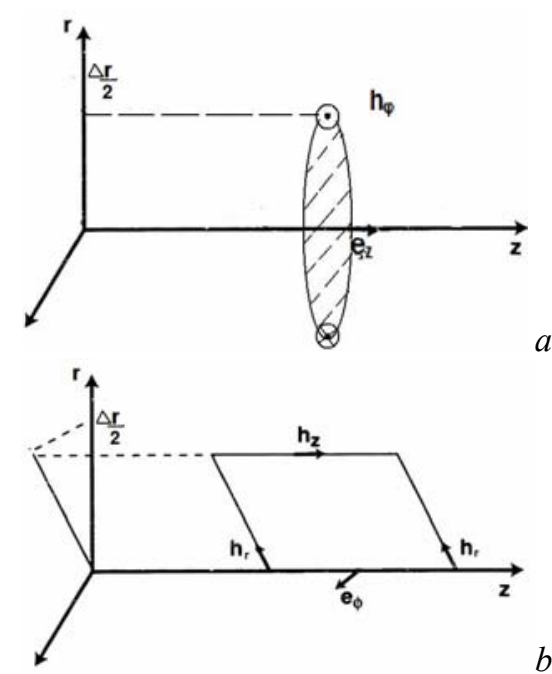

$b$

Fig.3. Calculation of electric field components $E_{z}(a)$ and $E_{\varphi}(b)$ near the axis of the system

\section{SPECIFICITY OF WEIGHTING PROCEDURE}

Procedure of current density weighting also has the specific features in cylindrical geometry. The current density in each node

$$
j=\frac{\Delta q}{\Delta t \Delta S},
$$

should be defined so that the continuity equation is fulfilled.

Weighting of the first order was used in the program, where large particles' cross-section has the square shape in the plane $(r, z)$. Therefore, they can distribute the charge to four cells simultaneously. In order to find the current density caused by each large particle it is necessary to trace how the particle passes through each edge of the elementary cell (Fig. 4) during each time step of simulation [6].

Maximum distance that particle can pass during one time step should not exceed the cell size (so called Courant condition):

$$
v_{\max } \Delta t \leq \Delta_{x} .
$$

Let's consider the possible variants of particle current distribution to the neighboring nodes. To reduce the quantity of the possible variants we use Courant condition in more hard form relatively to (8): limit maximum distance the particle passes per time step with to $\Delta_{x} / 2$.

During its move per time step the particle can give the contribution to 4 sides (Fig.4,a), to 7 sides (Fig.4,b), or to 10 sides (Fig.4,c).

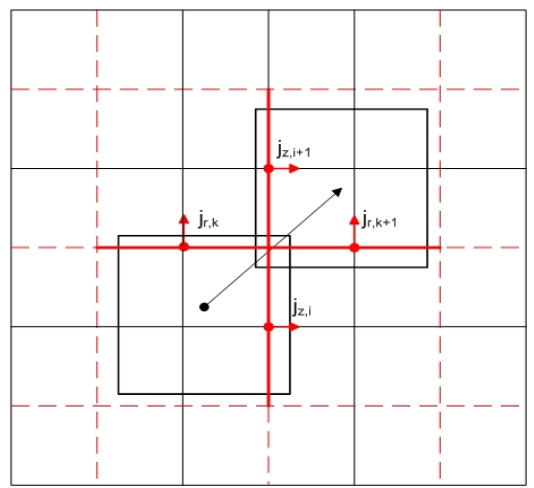

Fig. 4,a 


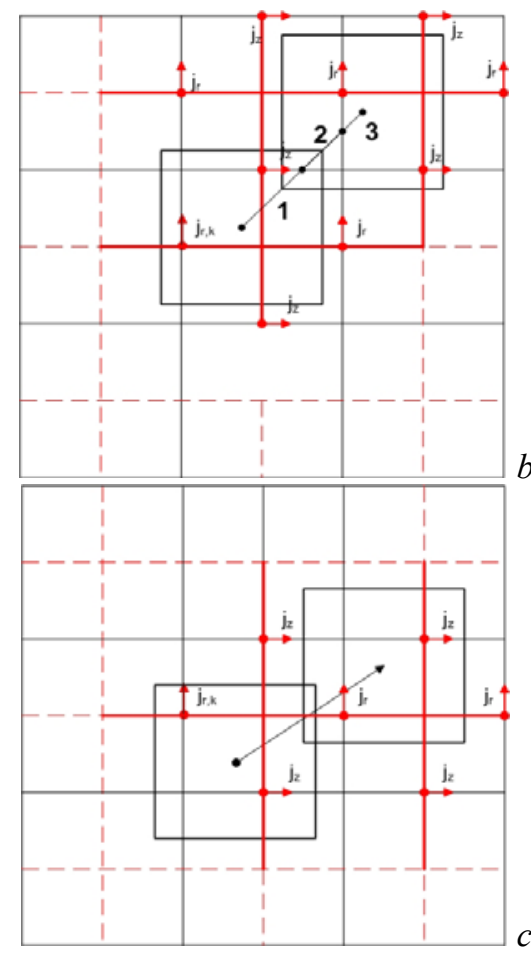

Fig.4. Weighting of the current density in the system

It is also necessary to consider that large particle charge density is a function of its radius, in contrast to be constant in the rectangular geometry.

\section{TEST SIMULATIONS OF \\ ELECTROMAGNETIC WAVE INTERACTING WITH INHOMOGENEOUS PLASMA}

A simulation volume has a form of cylindrical resonator with radius of $0,4 \mathrm{~m}$ and length of $12,8 \mathrm{~m}$. A cylindrical waveguide mode E01 with frequency $f=400 \mathrm{MHz}$ is excited by the rod with alternating current. It is located on the axis of the resonator and has a length of $0,37 \mathrm{~m}$. Electromagnetic absorbing layers is imposed on the both sides of resonator.

The system is partly filled with inhomogeneous plasma with linear density profile. The plasma consists of electrons and ions of hydrogen with near zero temperature.

The spatial distribution of $\mathrm{z}$ component of electric field for the case of wave interaction with subcritical inhomogeneous plasma is showed on Fig.6. The plasma density changes from $n_{\mathrm{p}}(\mathrm{z}=4,5 \mathrm{~m})=0,2 \cdot 10^{15} \mathrm{~m}^{-3}$ to $n_{\mathrm{p}}(\mathrm{z}=12,8 \mathrm{~m})=0,6 \cdot 10^{15} \mathrm{~m}^{-3}$. One can see that in this case the wave remains periodical but changes its wavelength while propagating through the plasma. This happens because subcritical plasma has lower dielectric permeability than vacuum that leads to the decrease of phase velocity of the wave.

The distribution of $\mathrm{z}$ component of electric field for the case of interaction with subcritical inhomogeneous plasma with the reflection point on the density profile is showed on Fig.5.

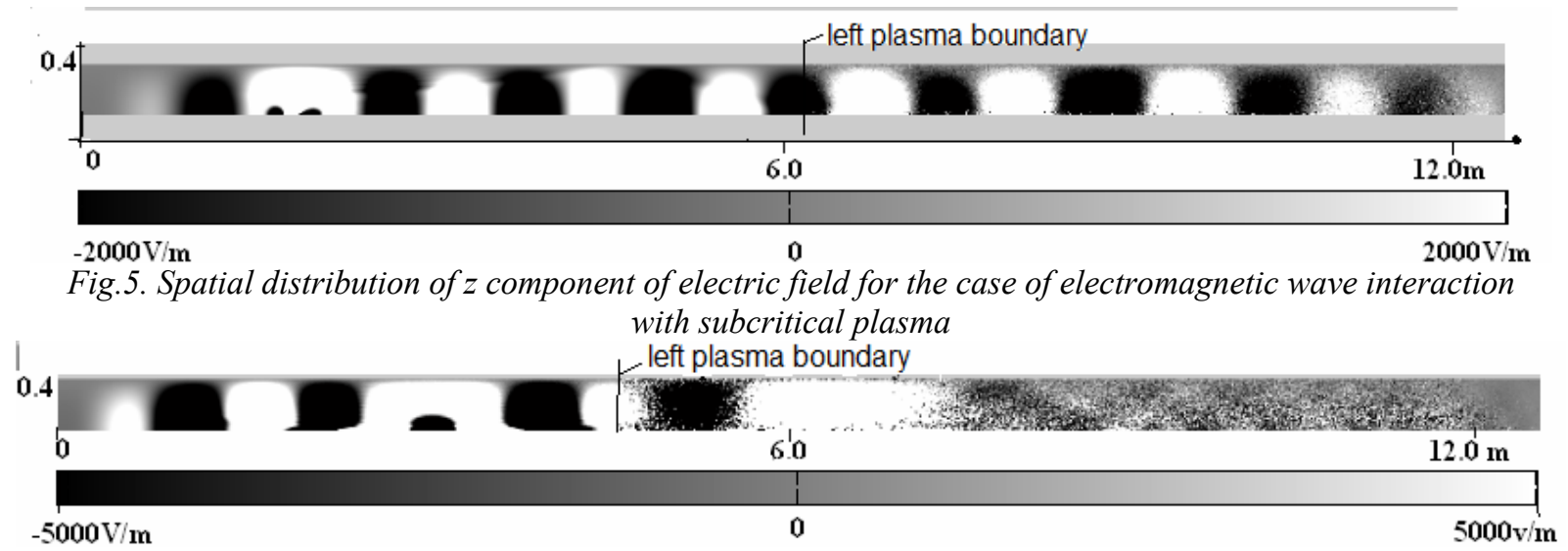

Fig.6. Spatial distribution of z component of electric field for the case of reflection of electromagnetic wave from the inhomogeneous plasma

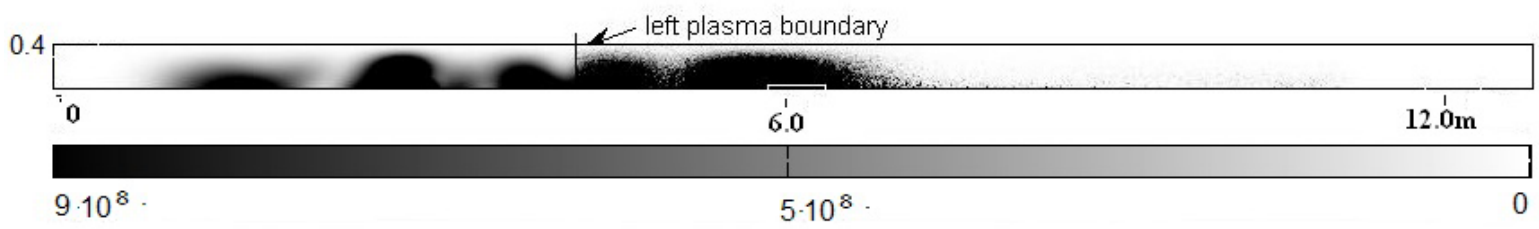

Fig. 7. Spatial distribution of intensity of electromagnetic field for the case of reflection of electromagnetic wave from the inhomogeneous plasma

The plasma density changes from

$$
\begin{gathered}
n_{\mathrm{p}}(\mathrm{z}=4,5 \mathrm{~m})=0,6 \cdot 10^{15} \mathrm{~m}^{-3}, \\
\text { to } n_{\mathrm{p}}(\mathrm{z}=12,8 \mathrm{~m})=1,5 \cdot 10^{15} \mathrm{~m}^{-3} .
\end{gathered}
$$

One can see that now the electromagnetic wave reflects from the inhomogeneous plasma. There are also low intensity oscillations of electric field beyond the reflection point which could be explained by generation of second harmonic.
The distribution of the intensity of the electric field is showed on the Fig.7. One can see that the standing wave is formed in plasma by the incident and the reflected wave. The reflection point is defined by the transversal wave number $\mathrm{k}_{\perp}$. It's well known from the theory [7] that in the case of non-zero angle $\theta$ between the wave number and the density gradient the reflection 
density is $\quad n_{r e f}=n_{c r} \sin ^{2} \theta=n_{c r} \frac{k^{2}-2 \pi v_{01} / R}{k^{2}}$,

(9)

where $n_{\mathrm{cr}}=1,9 \cdot 10^{15} \mathrm{~m}^{-3}$ is critical density, $R$ - radius of the resonator, $v_{01}=2.4$ - root of the Bessel's function. For parameters of simulation $n_{\text {ref }}=0,97 \cdot 10^{15} \mathrm{~m}^{-3}$. This value is close to the observed value of $n_{\text {ref, } \exp }=0,8 \cdot 10^{15} \mathrm{~m}^{-3}$.

\section{CONCLUSIONS}

The 2.5D electromagnetic relativistic PIC code for simulation of beam- and wave-plasma interaction in cylindrical geometry is presented in the paper. The accurate charge weighting scheme is introduced which allows the charge conservation law to be automatically fulfilled. The correctness of the program is confirmed by the comparison of simulation results with theoretical predictions.

\section{REFERENCES}

1. C.K. Birdsall, A.B. Langdon. Plasma Physics via Computer Simulation. McGraw-Hill book company, 1985.
2. I.O. Anisimiv, T.E. Litoshenko. Dynamics of a modulated electron beam in homogeneous plasma: 2d simulation // Ukrainian Journal of Physics. 2008, v.54, №4, p.388-392.

3. I.O. Anisimov, Yu.M. Tolochkevych. Dynamics of 1D electron bunch with the initially rectangular density profile injected into homogeneous plasma // Ukrainian Journal of Physics. 2009, v.54, №5, p.454-460.

4. A. Taflove, S.C. Hagness. Computational Electrodynamics: The Finite Difference Time Domain Method, Second edition. Artech House, 2000.

5. P. Russer, U. Siart. Finite Domain Methods in Electrodynamics // Springer Proceeding in Physcis. 2008.

6. J. Villasenor, O. Buneman. Rigorous charge conservation for local electromagnetic field solvers // Computer Physics Communications. 1992, v.69, p.306-316.

7. V.L. Ginzburg. Propagation of electromagnetic waves in plasmas. $2^{\text {nd }}$ edition. Moscow: «Nauka», 1967.

Статья поступила в редакциию 02.06.2010 г.

\subsection{D-РЕЛЯТИВИСТСКИЙ ЭЛЕКТРОМАГНИТНЫЙ КОД МЕТОДОМ ЧАСТИЦ ДЛЯ МОДЕЛИРОВАНИЯ ВЗАИМОДЕЙСТВИЯ ПУЧКА С ПЛАЗМОЙ В ЦИЛИНДРИЧЕСКОЙ ГЕОМЕТРИИ}

Ю.М. Толочкевич, Т.Е. Литоченко, И.А. Анисимов

2.5D-релятивистский электромагнитный код методом частиц был разработан для моделирования взаимодействия пучка с плазмой в цилиндрической геометрии. Была применена точная схема взвешивания заряда в ячейках, а также модификация метода конечных разностей возле оси системы. Были проведены тестовые запуски для моделирования взаимодействия электромагнитной волны с неоднородной плазмой.

\subsection{D-РЕЛЯТИВІСТСЬКИЙ ЕЛЕКТРОМАГНІТНИЙ КОД МЕТОДОМ ЧАСТИНОК ДЛЯ МОДЕЛЮВАННЯ ВЗАЕМОДІЇ ПУЧКА 3 ПЛАЗМОЮ В ЦИЛІНДРИЧНІЙ ГЕОМЕТРІЇ Ю.М. Толочкевич, Т.С. Літошенко, І.О. Анісімов}

2.5D-релятивістський електромагнітний код методом частинок був розроблений для моделювання взаємодії пучка 3 плазмою в циліндричній геометрії. Було застосовано точну схему зважування заряду в комірках, а також модифікація методу скінченних різниць біля осі системи. Було проведено тестові запуски для моделювання взаємодії електромагнітної хвилі з неоднорідною плазмою. 